\title{
Detection of Borrelia-specific 16S rRNA sequence in total RNA extracted from Ixodes ricinus ticks
}

[Detecção de sequência 16S rRNA, específica de Borrelia, em RNA total extraído de Ixodes ricinus]

\author{
Ž. Radulović ${ }^{1}$, M. Milutinović ${ }^{1}$, S. Tomanović ${ }^{1}$, A. Mulenga ${ }^{2}$ \\ ${ }^{1}$ Laboratory for Medical Arachnoentomology, Serbian Centre for Parasitic Zoonoses \\ Institute for Medical Research, University of Belgrade, Serbia \\ ${ }^{2}$ Department of Entomology, Texas A \& M University, TX, USA
}

\begin{abstract}
A reverse transcriptase - polymerase chain reaction based assay for Borrelia species detection in ticks was developed. The method was based on amplification of 552 nucleotide bases long sequence of $16 \mathrm{~S}$ rRNA, targeted by Borrelia specific primers. In the present study, total RNA extracted from Ixodes ricinus ticks was used as template. The results showed higher sensitivity for Borrelia detection as compared to standard dark-field microscopy. Method specificity was confirmed by cloning and sequencing of obtained 552 base pairs long amplicons. Phylogenetic analysis of obtained sequences showed that they belong to B. lusitaniae and B. afzelii genospecies. RT-PCR based method presented in this paper could be very useful as a screening test for detecting pathogen presence, especially when in investigations is required extraction of total RNA from ticks.
\end{abstract}

Keywords: Borrelia, RT-PCR, 16S rRNA, Ixodes ricinus

\section{RESUMO}

Para a detecção de espécies de Borrelia em carrapatos, desenvolveu-se a técnica da transcrição reversa, seguida da reação em cadeia da polimerase (RT-PCR). A técnica baseou-se na amplificação de 552 bases de nucleotídeos de 16S rRNA, utilizando-se primers específicos de Borrelia. O RNA total extraído de amostras de carrapatos Ixodes ricinus foi usado como modelo. Verificou-se maior sensibilidade da RT-PCR, para a deteç̧ão de Borrelia, em comparação com a microscopia de campo escuro padrão. A especificidade da técnica foi confirmada por clonagem e sequenciamento dos 552 pares de base obtidos. A análise filogenética das sequências obtidas revelou que pertencem a $\mathrm{B}$. lusitaniae e genospecies $\mathrm{B}$. afzelii. A RT-PCR apresentada neste trabalho poderá ser muito útil como teste de triagem para detectar a presença do patógeno. Especialmente quando em investigações, é necessária a extração total de RNA de carrapatos.

Palavras-chave: Borrelia, RT-PCR, $16 S$ rRNA, Ixodes ricinus

Recebido em 15 de dezembro de 2009

Aceito em 16 de julho de 2010

E-mail: zeljko@imi.bg.ac.rs 


\section{INTRODUCTION}

The genus Borrelia consists of many species of spirochetal bacteria that are human and animal pathogens. These organisms are responsible for two important disease groups: lyme borreliosis and relapsing fevers. With the exception of louse-borne $B$. recurrentis, causative agent of epidemic relapsing fever, Borrelia species are transmitted by ticks. Hard ticks of the genus Ixodes are vectors of B. burgdorferi sensu lato, species complex comprising 15 genospecies, some of which cause lyme borreliosis. On the other hand, the majority of endemic relapsing fever Borrelia species are vectored by soft ticks, while $B$. miyamotoi, B. theileri, and B. lonestari represent exceptions that are transmitted by hard tick species.

Since the only natural way for Borrelia infection is the bite of infected vector, the prevalence of these pathogens in ticks represents an important risk indicator for human populations. Studies on prevalence of lyme disease spirochetes in Ixodes ticks are particularly numerous (Stafford III et al., 1998; Hubálek and Halouzka, 1998; Rauter and Hartung, 2005). Generally used methods for detection of Borrelia in ticks are BSK medium cultivation, dark-field and phase-contrast microscopy, direct and indirect immunofluorescence, and PCR based assays. PCR is the most often used method because of its high sensitivity. Primary targets for PCR detection of Borrelia specific DNA sequences in ticks are genes encoding the major outer surface proteins, flagellin, and 16S rRNA (Persing et al., 1990). Development of nested-PCR and especially of real-time PCR based methods significantly increased sensitivity of Borrelia detection in ticks (Johnson et al., 1992; Wang et al., 2003). Ornstein and Barbour (2006) developed very sensitive $16 \mathrm{~S}$ rRNA based RT real-time PCR assay for detection and quantification of $B$. burgdorferi spirochetes in ticks.

Some authors reported that activity of Ixodid ticks is changed under the influence of Borrelia infection (Lefcort and Durden, 1996; Alekseev et al., 2000; Radulović et al., 2004). Besides, pathogen-induced expression of genes encoding antimicrobial peptides has been described in several tick species (Macaluso et al., 2003; Hynes et al., 2005; Rudenko et al., 2005).
Application of simple and fast assays for pathogen species specific sequences detection in nucleic acids extracted from ticks is very important for these kind of researches. The aim of the present study was to develop a method for testing ticks for borreliae presence by detection of Borrelia-specific sequences in total RNA extracted. Owing to differential expression of some borrelial genes encoding proteins during tick life cycle phases (Gilmore et al., 2001), the target was $16 \mathrm{~S}$ rRNA.

\section{MATERIAL AND METHODS}

Field collected unfed host-seeking adult Ixodes ricinus ticks were used for this study. Ticks were sampled by flagging vegetation in several localities in Serbia. Live ticks were kept individually in tubes containing a piece of damp paper until assay.

Ticks were tested for Borrelia infection by darkfield microscopy as previously described (Radulović et al., 2006). After dissection, body and internal organ parts of each individual tick were removed from physiological saline and immerged into RNAlater reagent (Ambion, Austin, TX, USA). Extraction of total RNA from dissected ticks was done using the Trizol reagent (Invitrogen, Carlsbard, CA, USA), following the protocol of the manufacturer.

Two new primers were designed, based on comparison of GenBank 16S rRNA gene sequences of the following Borrelia species: $B$. burgdorferi sensu stricto (M89938, X85195, U03396), B. afzelii (D67019, L46697, X85197), $B$. garinii (AB007450, D67018, X85198), B. lusitaniae (AB091822, X98226, X98228), B. valaisiana (AB022143, AB091463, EU135597), B. tanukii (AB030751, D67023, NR025874), B. japonica (L40597, L46695, L46696), B. bissettii (AJ224138, AJ224139, AJ224141), B. andersonii (L46688, L46701), B. turdi (D67022, D67024, NR025873), B. recurrentis (AF107367, DQ346813, U42300), B. crocidurae (DQ057989, U42302), B. duttonii (AF107366, AF107364, U42293), B. persica (U42297), B. hispanica (DQ057988, U42294), B. parkeri (AF307100, U42296), B. turicatae (AY604974, U42299), B. hermsii (DQ855529, DQ855530, U42292), $B$. lonestari (AY166715, AY682921), B. miyamotoi (GQ253925, NR025861), and B. coriceae 
(M60970, U42286). Primers were designed to target 552 base pairs long sequence. Forward primer (5'-GGC TTA GAA CTA ACG CTG GCA GTG C-3') was designed to match with Borrelia specific sequence of $16 \mathrm{~S}$ rRNA. On the other hand, reverse primer (5'-CCC TTT ACG CCC AAT AAT CCC GA-3') was designed to match with $16 \mathrm{~S}$ rRNA sequence conserved in Borrelia, Anaplasma, and Ehrlichia species. There was one nucleotide mismatch in the forward primer sequence in B. japonica and $B$. hermsii, and one in the reverse primer in $B$. hermsii, $B$. lonestari, and $B$. miyamotoi. Sequence alignment and oligonucleotide analysis were performed by Vector NTI Advance 10 software (Invitrogen, Carlsbard, CA, USA).

The RT-PCR assay was performed in $25 \mu \mathrm{L}$ volume comprising $1 \mu \mathrm{L}$ of RNA sample, $2 \mu \mathrm{L}$ of each primer $(10 \mu \mathrm{M})$, and adequate amounts of components of SuperScript(tm) One-Step RTPCR System for Long Templates (Invitrogen, Carlsbard, CA, USA). Reverse transcription was carried out for 30 minutes at $45^{\circ} \mathrm{C}$, followed by an initial PCR activation step for 2 minutes at $94^{\circ} \mathrm{C}$ and then 40 cycles for 15 seconds at $94^{\circ} \mathrm{C}$, 30 seconds at $54^{\circ} \mathrm{C}$ and one minute at $68^{\circ} \mathrm{C}$. A final extension step was performed at $72^{\circ} \mathrm{C}$ for seven minutes. Following amplification, $15 \mu \mathrm{L}$ of each PCR product was loaded onto $2 \%$ agarose gel containing ethidium bromide and separated in TAE buffer by $100 \mathrm{~V}$ for 30 minutes. Bands containing 552 base pairs long sequences were cut out and cDNA was extracted by StrataPrep DNA Gel Extraction Kit (Stratagene, La Jolla, CA, UCA). Cloning of recovered cDNA was performed by using pGEM-T Vector System I (Promega, Madison, WI, USA) and DH5 $\alpha$ Competent Cells (Invitrogen, Carlsbard, CA, USA). After transformation procedure, bacterial cells were spread on X-Gal agar plates with ampicillin and incubated overnight at $37^{\circ} \mathrm{C}$. Analysis of four to six white colonies from each plate, for the presence of the 552 base pairs long DNA insert, was performed by colony PCR. Colonies containing a DNA of interest were inoculated into $3 \mathrm{~mL}$ of LB broth with ampicillin and incubated for 12 hours at $37^{\circ} \mathrm{C}$ with shaking at 220 rotation per minute. Plasmid DNA from culture was extracted using Wizard Plus SV
Mini-Prep (Promega, Madison, WI, USA). Sequencing reactions were performed with the BigDye Terminator v3.1 Cycle Sequencing Kit and run on an 3730xl sequencer (Applied Biosystems, Foster City, CA, USA). New sequences were identified using NCBI BLAST homology search.

The GenBank accession numbers for the sequences reported in this paper are GU247968 GU247974. Phylogenetic analysis was performed with the ClustalW algorithm included within the MegaAlign module of the Lasergene software package (DNASTAR, Madison, WI, USA).

\section{RESULTS}

A total of 115 I. ricinus ticks were examined for the presence of Borrelia spp. by dark-field microscopy. Out of this number, 52 ticks were infected. Number of Borrelia spp. was low in 29 examined ticks, while infection rate was medium and high in 16 and seven, respectively.

Results obtained by the RT-PCR assay for amplification of 552 bases long 16S rRNA sequence showed the presence of borrelial RNA in total RNA extracted from ticks that had been indicated as infected by dark-field microscopy. Besides, amplification of 552 bases long sequence was detected in eight ticks that had been indicated as Borrelia uninfected (Fig. 1).

Fifteen 552 base pairs long amplicons obtained by RT-PCR assay, including eight amplicons originating from ticks that had been indicated as Borrelia uninfected by dark-field microscopy, were submitted to cloning and sequencing procedures, yielding seven different sequences. All obtained sequences, according to BLASTN searches against GenBank nucleotide databases, showed high homology with gene encoding $16 \mathrm{~S}$ rRNA of B. burgdorferi sensu lato genospecies. Phylogenetic tree indicated that five newly reported 552 base pairs long borrelial 16S rRNA gene nucleotide sequences arranged with $B$. lusitaniae sequences, while two remaining sequences were similar to B. afzelii (Fig. 2). 


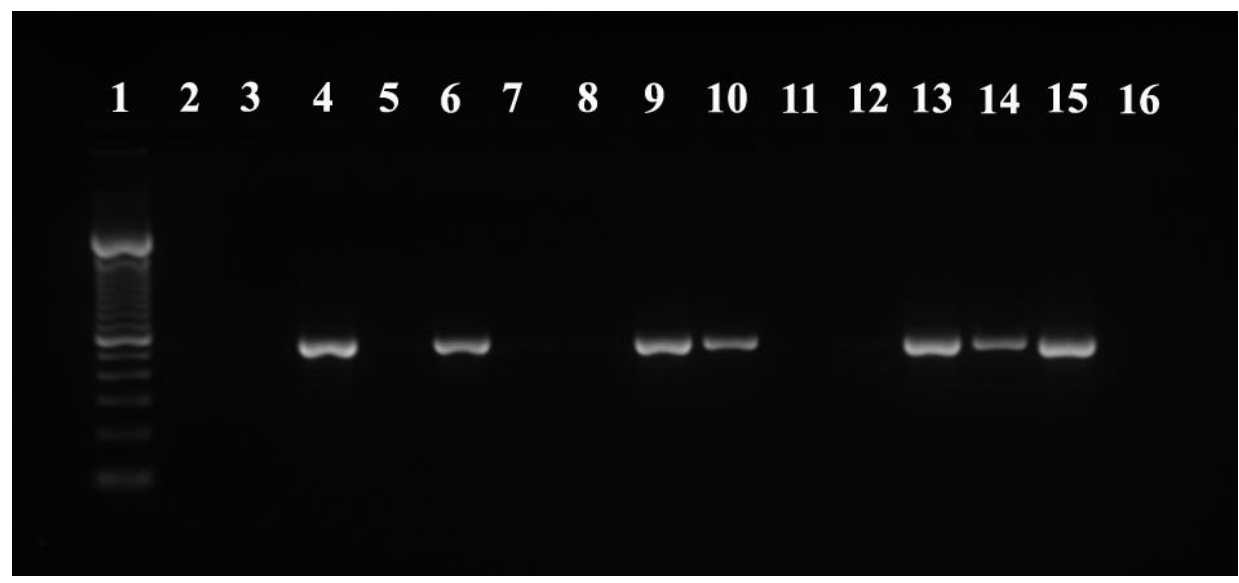

Figure 1. RT-PCR amplification of 552 bases long sequence of borrelial 16S rRNA in a total RNA extracted from Ixodes ricinus ticks. Lane 1: molecular weight marker; lanes 4 and 6: low infected ticks; lane 9: medium infected tick; lane 13: highly infected tick; lanes 2, 3, 5, 7, 8, 11, and 12: Borrelia uninfected ticks; lanes 10 and 14: ticks that had been indicated as Borrelia uninfected by dark-field microscopy, but with borrelial RNA detected by RT-PCR; lane 15: positive control; lane 16: negative control.

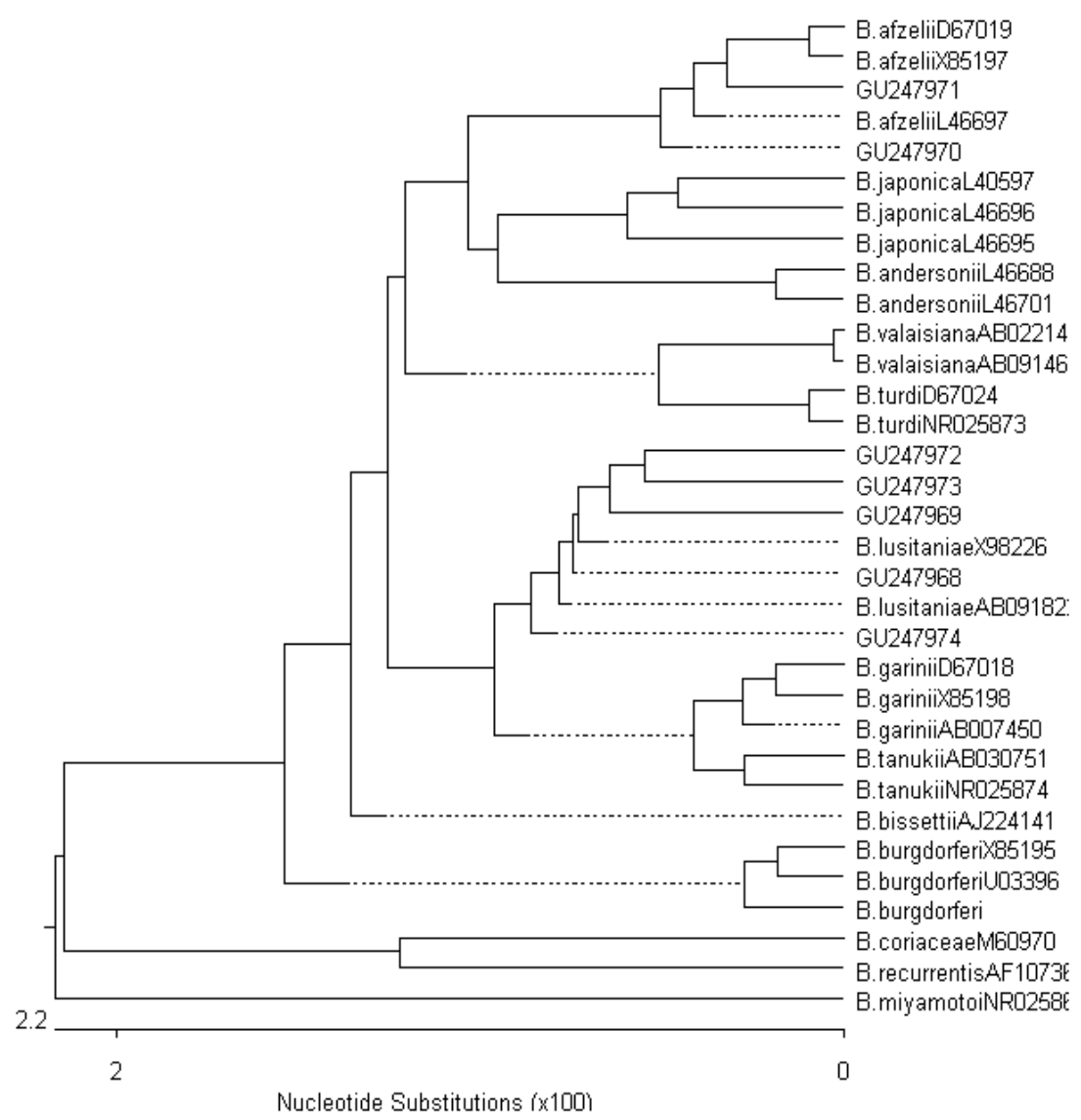

Figure 2. Phylogenetic tree based on 552 base pairs long sequence of borrelial gene encoding 16S rRNA. Accession numbers of newly reported sequences are in bold. 


\section{DISCUSSION}

Borrelia species have a single gene for $16 \mathrm{~S}$ rRNA per genome (Schwartz et al., 1992). In culture grown B. burgdorferi, the number of $16 \mathrm{~S}$ rRNA copies is $100-1,000$ times greater than that of gene copies (Ornstein and Barbour, 2006). Therefore, targeting 16S rRNA instead of gene encoding 16S rRNA increases method sensitivity, as previously described in some other bacterial pathogens (Rhodes et al., 1998; Felek et al., 2001). In the present study, borrelial rRNA was detected in 60 Borrelia-infected ticks, including 29 with less than 10 spirochetes per tick and eight without observed spirochetes by dark-field microscopy. The last indicated has been expected owing to higher sensitivity of PCR based methods for Borrelia detection as compared to dark-field microscopy (Wittenbrink et al., 1994). Nonspecific amplification as a possibility is excluded by sequencing the revealed amplicons. Homology of newly reported 552 base pairs long sequences with borrelial gene encoding 16S rRNA confirmed the specificity of the presented method.

Ixodes ricinus tick is generally known as a vector of Lyme disease Borrelia species: B. burgdorferi sensu stricto, B. afzelii, B. garinii, B. valaisiana, $B$. lusitaniae, and B. spielmanii. Detection of sequences similar to $16 \mathrm{~S}$ rRNA gene of $B$. burgdorferi sensu lato in examined I. ricinus ticks fulfilled previous expectations. Phylogenetic analysis of these sequences showed that they are similar to those of B. lusitaniae and B. afzelii. These results are in line with recently published results of Milutinović et al. (2008), who found five Borrelia genospecies in hostseeking adult $I$. ricinus ticks collected in Serbia, whereby $B$. lusitaniae was the most frequent. The phylogenetic relationships of Borrelia species are commonly estimated on the basis of flaB or $16 \mathrm{~S}$ rRNA gene sequences (Rich et al., 2001). Ribosomal RNA sequence, focused on in this study, could be useful for borreliae phylogenetic relatedness analysis.

Analysis of Borrelia species 16S rRNA gene sequences, targeted by each of primers designed during this study, showed its very high homology. Strong sequence conservation of these regions among Borrelia species points to possibility of using presented RT-PCR based method for the detection of relapsing fever borreliae, which has not been demonstrated in this study. In contrast to Borrelia specific forward primer, reverse primer sequence is also similar to Anaplasma and Ehrlichia 16S rRNA gene sequences. Therefore, this method could be a good starting point for the development of multi RT-PCR based assay for simultaneous detection of two or more tick-borne pathogens.

\section{CONCLUSIONS}

RT-PCR based method presented in this paper could be very useful as a screening test for detecting pathogen presence, especially when in investigations is required extraction of total RNA from ticks. This results showed suitable sensitivity and specificity of RT-PCR.

\section{ACKNOWLEDGEMENTS}

This work was supported by a grant from the Ministry of Science and Technological Development of the Republic of Serbia (Project No. 145002).

\section{REFERENCES}

ALEKSEEV, A.N.; JENSEN, P.M.; DUBININA, H.V. et al. Peculiarities of behaviour of taiga (Ixodes persulcatus) and sheep (Ixodes ricinus) ticks (Acarina: Ixodidae) determined by different methods. Folia Parasitol., v.47, p.147-153, 2000.

FELEK, S.; UNVER, A.; STICH, R.W. et al. Sensitive detection of Ehrlichia chaffeensis in cell culture, blood and tick specimens by reverse transcription-PCR. J. Clin. Microbiol., v.39, p.460-463, 2001.

GILMORE Jr, R.D.; MBOW, M.L.; STEVENSON, B. Analysis of Borrelia burgdorferi gene expression during life cycle phases of the tick vector Ixodes scapularis. Microbes Infec., v.3, p.799-808, 2001.

HUBÁlEK, Z.; HALOUZKA, J. Prevalence rates of Borrelia burgdorferi sensu lato in hostseeking Ixodes ricinus ticks in Europe. Parasitol. Res., v.84, p.167-172, 1998. 
HYNES, W.L.; CERAUL, S.M.; TODD, S.M. et al. A defensin-like gene expressed in the black-legged tick, Ixodes scapularis. Med. Vet. Entomol., v.19, p.339-344, 2005.

JOHNSON, B.J.B.; HAPP, C.M.; MAYER, L.W. et al. Detection of Borrelia burgdorferi in ticks by species-specific amplification of the flagellin gene. Am. J. Trop. Med. Hyg., v.47, p.730-741, 1992.

LEFCORT, H.; DURDEN, L.A. The effect of infection with Lyme disease spirochetes (Borrelia burgdorferi) on the phototaxis, activity, and questing height of the tick vector Ixodes scapularis. Parasitology, v.113, p.97-103, 1996.

MACALUSO, K.R.; MULENGA, A.; SIMSER, J.A. et al. Differential expression of genes in uninfected and Rickettsia-infected Dermacentor variabilis ticks as assessed by differential-display PCR. Infect. Immun., v.71, p.6165-6170, 2003.

MILUTINOVIĆ, M.; MASUZAWA, T.; TOMANOVIĆ, S. et al. Borrelia burgdorferi sensu lato, Anaplasma phagocytophilum, Francisella tularensis and their co-infections in host-seeking Ixodes ricinus ticks collected in Serbia. Exp. Appl. Acarol., v.45, p.171-183, 2008.

ORNSTEIN, K.; BARBOUR, A.G. A reverse transcriptase-polymerase chain reaction assay of Borrelia burgdorferi 16S rRNA for highly sensitive quantification of pathogen load in a vector. VectorBorne Zoonot., v.6, p.103-112, 2006.

PERSING, D.H.; TELFORD III, S.R.; RYS, P.N. et al. Detection of Borrelia burgdorferi DNA in museum specimens of Ixodes dammini ticks. Science, v.249, p.1420-1423, 1990.

RADULOVIĆ, Ž.; MILUTINOVIĆ, M.; ANĐELKOVIĆ, M. et al. Allozyme polymorphism of $M d h$ and $\alpha-G p d h$ in Ixodes ricinus populations: comparison of borreliae-infected and uninfected ticks. Exp. Appl. Acarol., v.40, p.113-121, 2006.

RADULOVIĆ, Ž.; MILUTINOVIĆ, M.; OREŠČANIN, Z. Activity parameters of borreliainfected and noninfected Ixodes ricinus ticks in host seeking under laboratory conditions. Vet. Glasnik, v.58, p.595-605, 2004. [in Serbian]
RAUTER, C.; HARTUNG, T. Prevalence of Borrelia burgdorferi sensu lato genospecies in Ixodes ricinus ticks in Europe: a metaanalysis. Appl. Environ. Microbiol., v.71, p.7203-7216, 2005.

RHODES, L.D.; NILSSON, W.B.; STROM, M.S. Sensitive detection of Renibacterium salmoninarum in whole fry, blood, and other tissues of Pacific salmon by reverse transcription-polymerase chain reaction. Mol. Mar. Biol. Biotechnol., v.7, p.270279, 1998.

RICH, S.M.; ARMSTRONG, P.M.; SMITH, R.D. et al. Lone star tick-infecting borreliae are most closely related to the agent of Bovine borreliosis. $J$. Clin. Microbiol., v.39, p.494-497, 2001.

RUDENKO, N.; GOLOVCHENKO, M.; EDWARDS, M.J. et al. Differential expression of Ixodes ricinus tick genes induced by blood feeding or Borrelia burgdorferi infection. J. Med. Entomol., v.42, p.36-41, 2005.

SCHWARTZ, J.J.; GAZUMYAN, A.; SCHWARTZ, I. rRNA gene organization in the Lyme disease spirochete, Borrelia burgdorferi. J. Bacteriol., v.174, p.3757-3765, 1992.

STAFFORD III, K.C.; CARTTER, M.L.; MAGNARELLI, L.A. et al. Temporal correlations between tick abundance and prevalence of ticks infected with Borrelia burgdorferi and increasing incidence of Lyme disease. J. Clin. Microbiol., v.36, p.1240-1244, 1998.

WANG, G.; LIVERIS, D.; BREI, B. et al. Realtime PCR for simultaneous detection and quantification of Borrelia burgdorferi in fieldcollected Ixodes scapularis ticks from the northeastern United States. Appl. Environ. Microbiol., v.69, p.4561-4565, 2003.

WITTENBRINK, M.M.; THIELE, D.; KRAUSS, H. Comparison of dark-field microscopy, culture, and polymerase chain reaction (PCR) for detection of Borrelia burgdorferi in field-collected Ixodes ricinus ticks. Zbl. Bakteriol., v.281, p.183-191, 1994. 